\title{
HUBUNGAN PENGETAHUAN ORANG TUA TENTANG GIZI DENGAN PERTUMBUHAN DAN PERKEMBANGAN ANAK USIA PRA SEKOLAH 4 TAHUN DI TK RA. RIYADHATUTHAHIRIYAH PAMBUSUANG KECAMATAN BALANIPA KABUPATEN POLEWALI MANDAR
}

\begin{abstract}
Umi Hani
Hasil-hasil studi dibidang neurologi mengetengahkan antara lain bahwa perkembangan anak telah mencapai 50\% ketika anak berusia 4 tahun, 80\% ketika anak berusia 8 tahun, dan genap 100\% ketika anak berusia 18 tahun (Osborn, White, dan Bloom). Studi tersebut makin menguatkan pendapat para ahli sebelumnya, tentang keberadaan masa peka atau masa emas (golden age) pada anak-anak usia dini. Masa emas perkembangan anak yang hanya datang sekali seumur hidup tidak boleh disia-siakan. Kurangnya pengetahuan orang tua tentang pentingnya gizi pada anak semakin memperburuk tumbuh kembang pada anaknya, hal ini berdampak pada kualitas Sumber Daya Manusia 20 tahun ke depan yang buruk.

Tujuan Penelitian ini adalah untuk menganalisis hubungan pengetahuan orang tua tentang gizi dengan pertumbuhan dan perkembangan Anak Prasekolah 4 tahun.

Metode Penelitian, yang digunakan adalah metode analitik dengan pendekatan Cros s sectional. Penelitian ini mengambil sampel 31 anak dan ibunya di TK RA. Riyadhatuthahiriyah Pambusuang kecamatan Balanipa kabupaten Polewali Mandar, yang mana tekhnik pengambilan sampel secara totalsampling yaitu Dimana Alat Ukur yang digunakan ialah Kuesioner serta alat timbangan berat badan dan lembar observasi. Yang mana dianalisis menggunakan uji Fisher's Exact Test dengan tingkat signifikansi $\alpha=0,05$.
\end{abstract}

Kepustakaan : 37 buku dari tahun 2007-2017, 3 Artikel dari Internet

\section{THE RELATION OF KNOWLEDGE OF PARENTS ABOUT NUTRITION WITH GROWTH AND THE DEVELOPMENT OF CHILDREN AGE SCHOOL PROGRAM 4 YEARS IN TK RA. RIYADHATUTHAHI- RIYAH PAMBUSUANG DISTRICT BALANIPA REGENCY OF POLEWALI MANDAR}

The results of neurology studies have included child development that has reached $50 \%$ when children aged 4 years, 80\% when children aged 8 years, and 100\% when 18 years old (Osborn, White, and Bloom). This study strengthens previous experts, about the present or golden age (golden age) in children of early age. The golden age of child development that is the only one that should never be wasted. Lack of knowledge of parents about nutrition problems in children further aggravate the growth and development of children, it affects the quality of Human Resources 20 years ahead of the bad.

The purpose of this study was to analyze the relationship of parents about nutrition with growth and development of 4-year preschoolers.

Research Methods, which used is analytical method with approach. This study took a sample of 31 children and her mother in TK RA. Riyadhatuthahiriyah Pambusuang Balanipa district Polewali Mandar district, where the sampling technique in total ie. Which is analyzed using Fisher's Exact Test with significance level $\alpha=0,05$.

Research results, statistical tests obtained with growth $(P=0.000)$ with response rate $(r=0,000)$ have a relationship with Knowledge of Parent neighbors.

Based on the results of research shows good knowledge of mother, will lead to growth of 4 year old pre school children. But the results of the researchers are still many who need in fix according to the direction of health workers so that encourage the work of health workers to improve its performance.

Keywords: Knowledge, Growth, Development, Nutrition.

Literature: 37 books from 2007-2017, 3 Articles from the Internet 


\section{PENDAHULUAN}

\section{Latar Belakang}

Keberhasilan pembangunan kesehatan ditandai oleh semakin meningkatnya derajat kesehatan masyarakat, mutu pelayanan prima, sarana dan prasarana yang memadai serta berprilaku hidup sehat yang mencerminkan pada tercapainya peningkatan pembangunan manusia baik dari segi kualitas sumber daya manusianya maupun faktor pendukung dari peningkatan pembangunan manusia itu sendiri sehingga tujuan dari apa yang diharapkan dapat tercapai.

Pembangunan Nasional jangka panjang menitik beratkan pada kualitas Sumber Daya Manusia (SDM) yang tangguh dan produktif. Tujuan tersebut dapat tercapai dengan upaya mengusahakan tumbuh kembang anak seoptimal mungkin setarap potensinya. Dalam usaha kelangsungan hidup perkembangan dan perlindungan anak juga tidak lepas dari tujuan membina SDM yang tangguh dan berkualitas (Hariweni, 2011).

Pertumhuhan dan perkembangan menurut WHO ialah perpaduan antara perubahan secara kualitatif dan kuantitatif pada balita. Pertumbuhan adalah proses pertambahan secara kualitatif seperti misalnya berat badan, tinggi badan, lingkar dada, lingkar kepala dan sebagainya. Sedangkan perkembangan adalah perubahan secara struktural dan fungsional misalnya motorik gerak, fungsi organ tubuh dan sebagainya. Keduanya merupakan satu kesatuan yang harus berjalan searah dan seimbang dalam tumbuh kembang anak. (Area Balita. 2015)

Hasil-hasil studi dibidang neurologi mengetengahkan antara lain bahwa perkembangan anak telah mencapai 50\% ketika anak berusia 4 tahun, $80 \%$ ketika anak berusia 8 tahun, dan genap 100\% ketika anak berusia 18 tahun (Osborn, White, dan Bloom). Studi tersebut makin menguatkan pendapat para ahli sebelumnya, tentang keberadaan masa peka atau masa emas (golden age) pada anak-anak usia dini. Masa emas perkembangan anak yang hanya datang sekali seumur hidup tidak boleh disia-siakan.

Anak merupakan kelompok yang menunjukan pertumbuhan yang sangat pesat sehingga memerlukan zat gizi yang tinggi setiap kilogram berat badannya. Peran orang tua sangat penting dalam pemenuhan gizi karena saat seperti ini anak sangat membutuhkan perhatian dan dukungan orang tua dalam menghadapi pertumbuhan dan perkembangan yang sangat pesat. Untuk mendapatkan gizi yang baik diperlukan pengetahuan gizi yang baik dari orang tua agar dapat menyediakan menu pilihan yang seimbang (Devi, 2012).

Laju pertumbuhan dan perkembangan pada setiap tahapan usia tidak sama, tergantung dari faktor keturunan, konsumsi gizi, perlakuan orang tua dan lingkungan terhadap anak (Sunartyo, 2007). Nutrisi adalah salah satu komponen yang penting dalam menunjang keberlangsungan proses pertumbuhan dan perkembangan. Apabila kebutuhan nutrisi 
seseorang tidak atau kurang terpenuhi maka dapat menghambat pertumbuhan dan perkembangan (Hidayat, 2007). Keadaan gizi meliputi proses penyediaan dan penggunaan gizi untuk pertumbuhan, perkembangan, pemeliharaan dan aktivitas. Masalah gizi merupakan masalah kesehatan masyarakat yang dipengaruhi oleh beberapa faktor, antara lain penyakit infeksi, konsumsi makanan, tingkat pendapatan keluarga, jumlah anggota keluarga, tingkat pendidikan ibu, tingkat pengetahuan ibu tentang gizi, pelayanan kesehatan, pendapatan keluarga, budaya pantang makanan, dan pola asuh gizi (Soekirman, 2010). Kelompok rentan gizi merupakan kelompok masyarakat yang paling mudah menderita kelainan gizi jika suatu masyarakat mengalami kekurangan penyediaan bahan makanan. Pada umumnya kelompok yang rentan gizi adalah anak balita, hal ini disebabkan karena anak balita mengalami proses pertumbuhan yang relatif pesat sehingga memerlukan zat-zat gizi dalam jumlah yang relatif besar pula (Sediaoetama, 2010)

Siti Zulaikah (2010) dalam penelitiannya menunjukkan bahwa terdapat hubungan dengan koefisien korelasi sebesar 0,225 antara status gizi anak dengan pertumbuhan dan perkembangan balita usia 2-3 tahun. Hasil penelitian dari Wellem Elseus Pormes, sefti Rompas dan Amatus yudi Ismanto tentang Hubungan Pengetahuan Orang Tua tetnang Gizi dengan Stunting pada anak usia 4 tahun menujukkan bahwa terdapat hubugan antara pengetahuan orang tua dengan stunting dimana koefisien korelasi sebesar 0,000. Hasil penelitian dari Noverad Dwi Rahmaulina tentang hubungan pengetahuan ibu tentang gizi dan tumbuh kembang anask serta stimulasi psikososial dengan perkembangan kognitif anak usia 2 -5 tahun menunjukkan teradapat hubungan yang nyata dan positif.

Novera Dwi Rahmaulina dan Dwi Hastuti (2011) dalam penelitiannya menunjukkan terdapat hubungan antara pengetahuan ibu tentang gizi dengan perkembangan kognitif anak usia 2-5 tahun dengan nilai $\mathrm{P}<0.05, \mathrm{r}=$ 0,244 .

Hasil studi pendahuluan yang penulis lakukan pada tanggal 23 November 2016 di TK Ra. Riyadhatuthahiriyah Pambusuang Kecamatan Balanipa Kabupaten Polewali Mandar. Jumlah siswanya sebanyak 31 orang, dengan metode wawancara terhadap 10 orang tua yang mempunya anak usia 4 tahun di dapatkan hasil sebagai berikut 7 orang tua menyatakan kurang memahami pentingnya gizi pada anak untuk pertumbuhan dan perkembangan anaknya dan 3 orang tua menyatakan sangat memperhatikan gizi yang di berikan pada anaknya karena ia tahu akan pentingnya gizi untuk kepintaran anaknya.

Hasil studi pendahuluan dalam menilai perkembangan anak dari 10 anak dari orang tua tersebut, menggunakan Denver Developmental Screening Test (DDST) di dapatkan 6 orang anak mengalami keterlambatan perkembangan. Keenam orang anak tersebut mengalami dua keterlambatan pada sektor personal sosial tidak mau bermain dengan anak lain dan tidak dapat membantu pekerjaan sederhana, kemudian 
sektor perkembangan bahasa tidak mampu mengikuti perintah dan belum dapat memakai kata. Padahal usia anak sudah 4 tahun, perkembangan anak tersebut termasuk kedalam klasifikasi perkembangan abnormal karena didapatkan 2 keterlambatan pada 2 sektor yaitu personal sosial dan bahasa, 2 orang anak mengalami 1 keterlambatan pada satu sektor dan hanya ada 2 orang yang tidak mengalami keterlambatan perkembangan.

Hasil studi pendahuluan dalam menilai pertumbuhan anak dengan menimbang berat badan anak dan tinggi badan anak serta umur anak dari 10 anak tersebut di dapatkan 7 dari anak tersebut pertumbuhannya tidak sesuai antara berat badan dan tinggi badan serta umurnya hasilnya anak dalam kategori pendek 4 orang dari 7 anak dan berat badan kurang 6 orang dari 7 orang anak sedangkan status gizi baik hanya terdapat 3 orang anak.

Kurangnya pengetahuan orang tua tentang pentingnya gizi pada anak semakin memperburuk tumbuh kembang pada anaknya, hal ini berdampak pada kualitas Sumber Daya Manusia 20 tahun ke depan yang buruk. Berdasarkan kenyataan ini, maka perlu dilakukan penelitian tentang hubungan antara pengetahuan orang tua tentang Gizi dengan pertumbuhan dan perkembangan anak usia Pra Sekolah 4 tahun dalam rangka meningkatkan derajat kesehatan anak demi kecerdasan anak bangsa.

\section{METODE PENELITIAN}

Jenis dan Metode Penelitian

\begin{tabular}{l}
\multicolumn{2}{c}{ Dalam penelitian desain yang } \\
digunakan adalah cross sectional yang \\
merupakan rancangan penelitian yang \\
pengukuran atau pengamatannya dilakukan
\end{tabular} secara stimultan pada satu saat (sekali waktu).

(Nursalam, 2009).

\section{Lokasi dan Waktu Penelitian}

Penelitian ini telah dilaksanakan setelah mendapat izin dari pihak terkait. Adapun pelaksanaan penelitian dilaksanakan pada bulan februari - bulan Juni tahun 2017 dan dapat diuraikan dalam tabel berikut ini.

\section{Populasi dan Sampel}

Populasi

Populasi dalam penelitian ini ialah keseluruhan anak usia Pra sekolah 4 tahun dan ibunya di TK RA. Riyadhatuthahiriyah Pambusuang yaitu sebanyak 17 orang.

Sampel

Sampel dalam penelitian ini total sampling yaitu keseluruhan populasi sebanyak 17 anak dan ibunya di TK RA. Riyadhatuthahiriyah Pambusuang kecamatan Balanipa kabupaten Polewali Mandar.

\section{HASIL DAN PEMBAHASAN}

\section{Hasil Penelitian}

Variabel Univariat

Pengetahuan Ibu

Pengetahuan ibu hamil tentang Gizi merupakan segala sesuatu yang diketahui dan atau kedalaman ibu terhadap Gizi. Adapun distribusi responden berdasarkan pengetahuan responden dapat dilihat pada tabel berikut : 
Tabel 4.5 Gambaran Distribusi Responden Berdasarkan Tingkat Pengetahuan Tentang Gizi Ibu Di TK RA. Riyadhatuthahiriyah Pambusuang

\begin{tabular}{|l|l|l|l|}
\hline No. & Tingkat Pengetahuan & F & \% \\
\hline 1 & Baik & 7 & 41,2 \\
\hline 2 & Cukup & 3 & 17,6 \\
\hline 3 & Kurang & 7 & 41,2 \\
\hline \multicolumn{2}{|l|}{ Jumlah } & $\mathbf{1 7}$ & $\mathbf{1 0 0}$ \\
\hline
\end{tabular}

Sumber : Data Primer Tahun 2017

Dari tabel 4.5 diatas dapat diketahui bahwa kisaran tingkat pengetahuan responden tentang gizi di TK. RA. Riyadhatuthahiriyah Kabupaten Polewali Mandar adalah kategori pengetahuan baik sebanyak $7 \quad(41,2 \%)$ responden, kategori pengetahuan cukup sebanyak $3(17,6 \%)$ responden dan kategori pengetahuan kurang sebanyak $7(41,2 \%)$ responden.
Pertumbuhan Anak Usia prasekolah 4 Tahun

Pertumbuhan anak usia pra sekolah 4 tahun merupakan Perubahan dalam besar, jumlah, ukuran atau dimensi tingkat sel, organ maupun individu pada usia 4 tahun. Adapun distribusi responden berdasarkan pertumbuhan responden dapat dilihat pada tabel berikut :

Tabel 4.6 Gambaran Distribusi Responden Berdasarkan Pertumbuhan Anak Usia Prasekolah 4 Tahun Di TK RA. Riyadhatuthahiriyah Pambusuang

\begin{tabular}{|l|l|l|l|}
\hline No. & Pertumbuhan & F & \% \\
\hline 1 & Sesuai & 9 & 41,2 \\
\hline 2 & Tidak Sesuai & 8 & 17,6 \\
\hline \multicolumn{2}{|l}{ Jumlah } & $\mathbf{1 7}$ & $\mathbf{1 0 0}$ \\
\hline
\end{tabular}

Sumber : Data Primer Tahun 2017

Dari tabel 4.6 diatas dapat diketahui bahwa kisaran pertumbuhan responden di TK. RA. Riyadhatuthahiriyah Kabupaten Polewali
Mandar adalah kategori sesuai sebanyak $9(52,9$ $\%$ ) responden dan kategori tidak sesuai sebanyak $8(47,1 \%)$ responden. 
Perkembangan Anak Usia prasekolah 4

Tahun

Perkembangan anak usia pra sekolah 4 tahun merupakan bertambahnya kemampuan (skill) dalam struktur dan fungsi tubuh yang

Tabel 4.7 Gambaran Distribusi Responden Berdasarkan Perkembangan Anak Usia Prasekolah 4 Tahun Di TK RA. Riyadhatuthahiriyah Pambusuang

\begin{tabular}{|l|l|l|l|}
\hline No. & Perkembangan & F & \% \\
\hline 1 & Normal & 9 & 52,9 \\
\hline 2 & Abnormal & 8 & 47,1 \\
\hline \multicolumn{2}{|l|}{ Jumlah } & $\mathbf{1 7}$ & $\mathbf{1 0 0}$ \\
\hline
\end{tabular}

Sumber : Data Primer Tahun 2017 bahwa kisaran perkembangan responden di TK. RA. Riyadhatuthahiriyah Kabupaten Polewali lebih komplek pada usia 4 tahun. Adapun distribusi responden berdasarkan perkembangan responden dapat dilihat pada tabel berikut :

\section{Sumber. Data Primer Tahun 2017}

Dari tabel 4.7 diatas dapat diketahui
Mandar adalah kategori normal sebanyak 9 $(52,9 \%)$ responden, dan kategori abnormal sebanyak $8(47,1 \%)$ responden.

Tabel 4.8 Analisa Hubungan Pengetahuan Ibu Tentang Gizi Dengan pertumbuhan anak usia prasekolah 4 tahun Di TK RA. Riyadhatuthahiriyah Pambusuang

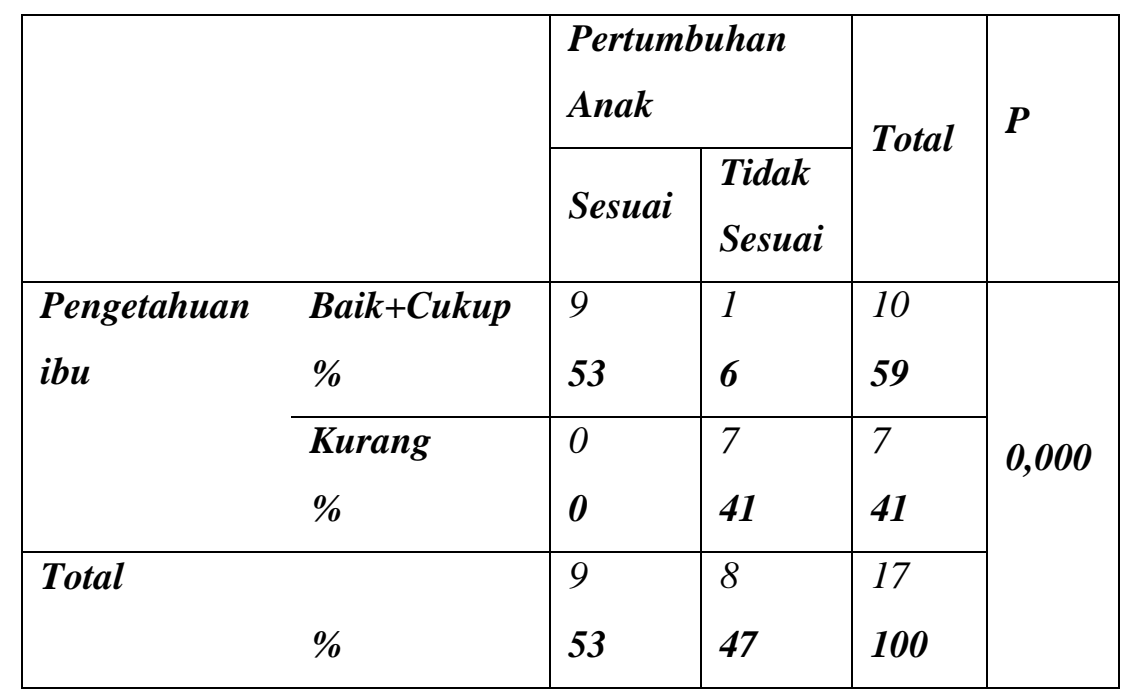

Sumber : Data Primer Tahun 2017

Dari tabel 4.8 tabulasi silang pertumbuhan anak usia prasekolah 4 tahun, pengetahuan ibu tentang gizi dengan dimana responden yang mempunyai 
pengetahuan baik+Cukup dengan pertumbuhan yang sesuai yaitu $53 \%$ atau 9 responden, yang mempunyai pengetahuan baik+Cukup dengan pertumbuhan yang tidak sesuai yaitu $6 \%$ atau 1 responden, dan pengetahuan kurang dengan pertumbuhan yang tidak sesuai ialah $41 \%$ atau 7 responden. Hal tersebut berdasarkan hasil analisa hubungan kedua variabel diatas dengan menggunakan uji statistik Fisher's Exact Test didapat signifikansi dari hubungan kedua variabel tersebut adalah $\mathrm{p}=0.000$, hal ini menyatakan adanya hubungan antara tingkat pengetahuan ibu dengan pertumbuhan anak usia prasekolah 4 tahun.

Pengetahuan Ibu dengan

Perkembangan Anak

Analisa hubungan pengetahuan ibu tentang gizi dengan Perkembangan anak usia prasekolah 4 tahun dapat di lihat pada tabel berikut :

Tabel 4.9 Analisa Hubungan Pengetahuan Ibu Tentang Gizi Dengan Perkembangan anak usia prasekolah 4 tahun Di TK RA. Riyadhatuthahiriyah Pambusuang

\begin{tabular}{|c|c|c|c|c|c|}
\hline & \multicolumn{2}{|c|}{$\begin{array}{l}\text { Perkembangan } \\
\text { Anak }\end{array}$} & \multirow[t]{2}{*}{ Total } & \multirow[t]{2}{*}{$P$} \\
\hline & & Normal & Abnormal & & \\
\hline \multirow[t]{2}{*}{$\begin{array}{l}\text { Pengetahuan } \\
\text { ibu }\end{array}$} & $\begin{array}{l}\text { Baik+Cukup } \\
\%\end{array}$ & $\begin{array}{l}9 \\
53\end{array}$ & $\begin{array}{l}1 \\
6\end{array}$ & $\begin{array}{l}10 \\
59\end{array}$ & \multirow{3}{*}{0,000} \\
\hline & $\begin{array}{l}\text { Kurang } \\
\%\end{array}$ & $\begin{array}{l}0 \\
0\end{array}$ & $\begin{array}{l}7 \\
41\end{array}$ & $\begin{array}{l}7 \\
41\end{array}$ & \\
\hline Total & $\%$ & $\begin{array}{l}9 \\
53\end{array}$ & $\begin{array}{l}8 \\
47\end{array}$ & $\begin{array}{l}17 \\
100\end{array}$ & \\
\hline
\end{tabular}

Sumber : Data Primer Tahun 2017

Dari tabel 4.9 tabulasi silang pengetahuan ibu tentang gizi dengan pertumbuhan anak usia prasekolah 4 tahun, dimana responden yang mempunyai pengetahuan baik+Cukup dengan perkembangan yang Normal yaitu $53 \%$ atau 9 responden, yang mempunyai pengetahuan baik+Cukup dengan perkembangan yang tidak sesuai yaitu $6 \%$ atau 1 responden, dan pengetahuan kurang dengan pertumbuhan yang tidak sesuai ialah $41 \%$ atau 7 responden. Hal tersebut berdasarkan hasil analisa hubungan kedua variabel diatas dengan menggunakan uji statistik Fisher's Exact Test didapat signifikansi dari hubungan kedua variabel tersebut adalah $\mathrm{p}$ $=0.000$, hal ini menyatakan adanya hubungan antara tingkat pengetahuan ibu dengan pertumbuhan anak usia prasekolah 4 tahun.

\section{Pembahasan}

\section{Pengetahuan Ibu}

Hasil penelitian ini menunjukkan bahwa 7 responden $(49,3 \%)$ berada pada kategori pengetahuan baik, dan 3 responden $(44,9 \%)$ berada pada kategori pengetahuan 
cukup, sedangkan 7 responden $(5,8 \%)$ dalam pengetahuan kurang.

Pengetahuan adalah hasil tahu dan ini terjadi setelah orang melakukan pemngindraan terhadap objek tertentu. Pengetahuan menurut winkel adalah mencakup ingatan akan hal-hal yang pernah dipelajari dan disimpan dalam bentuk ingatan.

Seimbangnya tingkat pengetahuan tentang Gizi antara tingkat pengetahuan baik dan kurang didukung oleh tingkat pendidikan responden seimbang antara pendidikan tinggi dan rendah serta lebih banyak berpendidikan SLTP. Seimbangnya pengetahuan responden bukan hanya dari pendidikan formal tidak mendukung bukan berarti pengetahuan responden akan rendah pula, hal ini karena pengetahuan bukan hanya di dapatkan dari pendidikan formal saja namun juga di dapatkan dari pendidikan informal.

Seimbangnya tingkat pengetahuan ibu tentang Gizi dapat dijelaskan juga karena pada saat evaluasi aspek-aspek yang berkaitan dengan gizi, beberapa ibu telah memiliki beberapa anak dan beberapa ibu yang baru memiliki anak, dengan begitu pengalaman seorang ibu dalam memberikan gizi pada anaknya berbeda dengan ibu yang baru memiliki anak.

\section{Pertumbuhan Anak}

Hasil penelitian ini menunjukkan bahwa sebanyak 9 (52,9\%) responden yang sesuai dengan pertumbuhannya dan tidak sesuai dengan pertumbuhannya sebanyak $8(47,1 \%)$ responden.

Pertumbuhan (growth) berkaitan dengan masalah pertumbuhan dalam besar, jumlah, ukuran atau dimensi tingkat sel, organ maupun individu yang bisa diukur dengan ukuran berat (gram, pound, kilogram), ukuran panjang ( $\mathrm{cm}$, meter), ukuran tulang dan keseimbangan metabolik (Soetjiningsih, 2013)

Berat badan merupakan ukuran antropometrik yang terpenting dan diukur pada setiap kesempatan memeriksa kesehatan anak pada semua kelompok umur. Berat badan merupakan hasil peningkatan/penurunan semua jaringan pada tubuh, antara lain tulang, otot, lemak, dan cairan tubuh. Pada saat ini berat badan di pakai sebagai indikator yang terbaik untuk mengetahui keadaan gizi dan tumbuh kembang anak karena berat badan sensitif terhadap perubahan walaupun sedikit. Pengukurannya bersifat objektif dan dapat diulangi dengan menggunakan timbangan apa saja yang relatif murah, mudah, dan tidak memerlukan banyak waktu. Kerugian indikator berat badan adalah tidak sensitif terhadap proporsi tubuh, misalnya pendek gemuk/tinggi kurus. Terdapat fluktuasi BB yang wajar dalam sehari sebagai akibat dari asupan (intake) makanan dan minuman, dengan luaran (output) melalui urin, feses, keringat dan nafas. Besarnya fluktuasi tergantung pada kelompok umur dan bersifat individual, yaitu berkisar antara 100-200 gram sampai 500-1000 gram bahkan lebih (Soetjiningsih, IG. N. Gde Ranuh, 2014) 
Pertumbuhan anak yang sesuai di dukung oleh perhatian oleh ibunya tentang gizi dan pertumbuhan yang tidak sesuai karena kurang tahunya ibu tentang gizi dan berakibat pada asumsi yang penting mengenyangkan tanpa melihat kandungan gizi dari setiap makanan olahan.

Dominasi hampir seimbangnya pertumbuhan balita yang sesuai dan tidak sesuai didukung oleh pengetahuan ibu balita yang seimbang pula dimana semakin tinggi pengetahuan seseorang maka timbullah prilaku positip yaitu pemberian nutrisi kepada balitanya agar kesehatannya dapat meningkat, begitupun sebaliknya.

\section{Perkembangan Anak}

Hasil penelitian ini menunjukkan bahwa sebanyak 9 (52,9\%) responden yang normal dengan perkembangannya dan tidak normal dengan perkembangannya sebanyak 8 $(47,1 \%)$ responden.

Perkembangan anak normal karena memang pada usia prasekolah guru telah memberikan berbagai macam bentuk stimulasi tumbuh kembang anak, salah satunya adalah melalui kegiatan bermain. Beberapa ahli mengatakan bahwa bermain pada anak merupakan sarana untuk belajar. Bermain dan belajar untuk anak merupakan suatu kesatuan dan suatu proses yang terus menerus terjadi dalam kehidupannya. Bermain merupakan tahap awal dari proses belajar pada anak yang dialami hampir semua orang. Melalui kegiatan bermain yang menyenangkan, seorang anak berusaha untuk menyelidiki dan mendapatkan pengalaman yang banyak. Baik pengalaman dengan dirinya sendiri,orang lain maupun dengan lingkungan sekitarnya. Melalui bermain anak dapat mengorganisasikan berbagai pengalaman dan kemampuan kognitifnya dalam upaya menyusun kembali gagasan yang cemerlang (IDAI, 2011).

Tidak abnormalnya perkembangan beberapa anak, disebabkan masih kurang berbaurnya anak tersebut kepada teman sebaya lainnya dan masih tidak mau jauh dari ibunya saat mengantar anaknya. Serta masih malu malu dengan gurunya saat di ajak belajar.

\section{Hubungan Pengetahuan Ibu dan Pertumbuhan Anak}

Dari hasil uji statistik Fisher's Exact Test didapat signifikansi dari hubungan kedua variabel tersebut adalah $\mathrm{p}=0.000$, hal ini menyatakan adanya hubungan antara tingkat pengetahuan ibu dengan pertumbuhan anak usia prasekolah 4 tahun.

Menurut Lawerence Green seperti dikuti Notoatmojo (2013) yang menganalisis faktor-faktor yang mempengaruhi perilaku manusia dari tingkat kesehatan salah satunya adalah pengetahuan yang merupakan predisposing factor.

Dengan pengetahuan yang tinggi maka akan berdampak pada prilaku yang baik sehingga berdampak pada peningkatan derajat hidup seseorang.

Menurut Lawerence Green seperti dikutip Notoatmojo (2003) yang menganalisis faktor-faktor yang mempengaruhi perilaku manusia dari tingkat kesehatan salah satunya adalah pengetahuan yang merupakan predisposing factor. Pernyataan tersebut didukung oleh WHO, seperti dikutip Notoatmojo (2003) bahwa pengetahuan yang 
diperoleh dari pengalaman sendiri atau pengalaman orang lain dapat menentukkan seseorang untuk berperilaku tertentu.

Pengetahuan responden yang baik+cukup tentang Gizi mempunyai pertumbuhan tidak sesuai di akibatkan oleh jarangnya ibu di rumah akibat kesibukan ibu sebagai tenaga guru, sehinnga terkadang anaknya di suruh jajan dan berdampak pada nilai gizi yang kurang akibat kurang kontrol dari ibunya. Sedangkan tingginya tingkat pengetahuan di hubungkan dengan pertumbuhan anak yang sesuai sebanyak 9 anak hal ini disebabkan oleh banyaknya orang tua responden bekerja sebagai nelayan jadi anak terbiasa mengonsumsi ikan sebagai sumber protein hewani yang baik untuk pertumbuhan. Hal ini sejalan dengan Soetjiningsih (1995) yang menyatakan bahwa pekerjaan/pendapatan orang tua yang memadai akan menunjang tumbuh kembang anak karena orang tua dapat menyediakan semua kebutuhan anak baik primer maupun sekunder.

Adanya pengetahuan responden yang kurang dengan pertumbuhan yang tidak normal, hal ini di akibatkan karena tingkat pendidikan responden tergolong rendah, sehingga berakibat pada penerimaan informasi yang kurang khususnya gizi dan berdampaka pada pola pikir dan prilaku yang negatif.

\section{Hubungan Pengetahuan ibu dengan Perkembangan Anak}

Dari hasil uji statistik Fisher's Exact Test didapat signifikansi dari hubungan kedua variabel tersebut adalah $\mathrm{p}=0.000$, hal ini menyatakan adanya hubungan antara tingkat pengetahuan ibu dengan pertumbuhan anak usia prasekolah 4 tahun.

Dalam perkembangan anak terdapat masa kritis, dimana diperlukan stimulasi yang berguna agar potensi berkembang, sehingga perlu mendapat perhatian. Perkembangan psiko-sosial sangat dipengaruhi lingkungan dan interaksi antara anak dengan orang tuanya/orang dewasa lainnya. Perkembangan anak akan optimal bila interaksi sosial diusahakan sesuai dengan kebutuhan anak pada berbagai tahap perkembangannya, bahkan sejak bayi masih di dalam kandungan. Sedangkan lingkungan yang tidak mendukung akan menghambat perkembangan anak.

Unsur-unsur yang berpengaruh dalam perkembangan anak adalah orang tua, keluarga, masyarakat, serta lingkungan tempat ia tumbuh dan berkembang. Interaksi anak dengan orang tua akan menimbulkan keakraban yang berpengaruh terhadap perkembangan anak yang tidak tertutup. Orang tua memegang peranan terbesar dalam mendidik anak (Herlina, 2010). Orang tua memiliki peran yang penting untuk merangsang potensi yg dimiliki oleh anak. Tugas pengasuhan umumnya diserahkan kepada ibu yang didasarkan pada pengetahuan yang dimilikinya. Salah satu faktor yang mempengaruhi pengetahuan adalah tingkat pendidikan ibu. Apabila ibu memiliki pengetahuan yang tinggi maka akan lebih aktif dalam mencari informasi untuk meningkatkan keterampilan dalam pengasuhan anak (Hastuti, 2010).

Penelitian ini bersesuaian dengan penelitian yang dilakukan oleh Latifah, tentang stimulasi pendidikan dalam rangka 
mengembangkan kemampuan kognitif, motorik, serta sosial emosi anak, menunjukkan bahwa terdapat hubungan yang signifikan positif antara pengetahuan ibu mengenai Status gizi dengan stimulasi psikososial. Dengan demikian dapat disimpulkan bahwa semakin baik tingkat pendidikan orang tua berhubungan erat dengan semakin baiknya kualitas perkembangan anak yang diberikan kepada anaknya (Latifah, 2010).

Dari hasil penelitian ini juga dominasinya normal perkembangan balita juga disebabkan oleh adanya proses stimulasi perkembangan dalam metode pembelajaran dan lebih banyk bermain hal ini akan mempengaruhi tingkat perkembangan anak itu sendiri.

Studi yang dilakukan di Kota Cimahi dengan menggunakan metode pemberian intervensi pada ibu. Penelitian ini dibagi menjadi 2 kelompok, yaitu kelompok kontrol yang tidak diberi intervensi dan kelompok perlakuan yang diberi intervensi berupa penyuluhan dan stimulasi. Menunjukkan perubahan yang sangat mendasar pada kontrol dan perlakuan. Berdasarkan hasil penelitian ditemukan perbedaan tingkat perkembangan balitanya (Aminah, 2008). Berdasarkan hasil penelitian dari wawancara anak saat melakukan DDST oleh Herlina (2010), sebagian besar anak yang memiliki perkembangan diduga mengalami kegagalan dalam sektor personal sosial dan motorik halus dikarenakan orang tua yang jarang bahkan tidak pernah mengajari anaknya. Mereka cenderung membiarkan anaknya berkembang apa adanya, bahkan jarang berinteraksi dan memberikan stimulasi kepada anaknya dikarenakan kesibukan orang tua.

Dengan pengetahuan yang tinggi maka akan berdampak pada prilaku yang baik sehingga berdampak pada peningkatan derajat hidup seseorang.

Menurut Lawerence Green seperti dikutip Notoatmojo (2003) yang menganalisis faktor-faktor yang mempengaruhi perilaku manusia dari tingkat kesehatan salah satunya adalah pengetahuan yang merupakan predisposing factor. Pernyataan tersebut didukung oleh WHO, seperti dikutip Notoatmojo (2003) bahwa pengetahuan yang diperoleh dari pengalaman sendiri atau pengalaman orang lain dapat menentukkan seseorang untuk berperilaku tertentu.

Pengetahuan responden yang baik+cukup tentang Gizi mempunyai perkembanga tidak sesuai di akibatkan oleh jarangnya ibu di rumah akibat kesibukan ibu sebagai tenaga guru, sehinnga terkadang anaknya di suruh jajan dan berdampak pada nilai gizi yang kurang akibat kurang kontrol dari ibunya. Sedangkan tingginya tingkat pengetahuan di hubungkan dengan perkembangan anak yang normal sebanyak 9 anak hal ini disebabkan oleh

\section{KESIMPULAN DAN SARAN}

\section{Kesimpulan}

Data yang diperoleh dari hasil penelitian mengenai hubungan pengetahuan orang tua tentang Gizi dengan pertumbuhan dan perkembangan anak usia prasekolah 4 tahun di TK. RA. Ridayatullah Pambusuang di Kabupaten Polewali Mandar tahun 2017 adalah sebagai berikut : 
Pengetahuan orang tua tentang Gizi dalam kategori baik+Cukup yaitu sebanyak $10(58,8$ $\%)$ responden.

Pertumbuhan anak usia pra sekolah 4 tahun didapatkan $9 \quad(41,2 \%)$ responden sesuai pertumbuhan.

perkembangan anak usia pra sekolah 4 tahun didapatkan $9 \quad(52,9 \%)$ responden Perkembangan Normal.

Adanya hubungan antara pengetahuan tentang gizi dengan pertumbuhan dan perkembangan anak usia prasekolah 4 tahun dimana $\mathrm{p}=0,000$

Penilitian ini menyimpulkan bahwa adanya pengaruh antara pengetahuan ibu tentang gizi akan berhubungan dengan tumbuh kembang anak usia prasekolah.

\section{Saran}

Bagi Pembaca

Peneliti menyarankan agar pembaca dapat lebih memahami tentang gizi dan dapat ber pengaruh terhadap prilaku dalam memilih makanan yang memenuhi gizi seimbang dan berdampak pada tumbuh kembang anak.

Bagi TK. RA. Hidayatullah

Peneliti menyarankan agar guru dapat memberikan stimulasi bagi muridnya sehingga dapat menunjang perkembngan si balita dan dapat memberi pemahaman kepada siswa agar dapat memberikan informasi tentang pentingnya gizi dalam proses tumbuh kembang. Bagi Institusi Pendidikan

Peneliti menyarankan agar hasil penelitian ini dapat dijadikan referensi pendukung secara ilmiah dalam penelitian dan keilmuan selanjutnya, dalam hal pengembangan ilmu keperawaatan khususnya keperawatan anak.
Bagi Profesi Keperawatan

Peneliti menyarankan agar mengadakan penyuluhan terhadap keluarga akan pentingya zat gizi untuk pertumbuhan dan perkembangan anak, sehngga berdampak pada meningkatkan sehingga mal nutrisi dapat di cegah.

Bagi peneliti selanjutnya

Peneliti menyarankan pada penelitian selanjutnya dapat melakukan studi mengenai faktor-faktor lain yang mempengaruhi tumbuh kembang balita dan mengidentifikasi faktor yang menyebabkan masih tingginya angka gizi buruk di wilayah kabupaten Polewali Mandar.

\section{DAFTAR PUSTAKA}

Achmad, Djaeni Sediaoetama. 2008. Ilmu Gizi untuk mahasiswa dan profesi jilid I. Jakarta: Dian Rakyat.

Almatsier, sunita. 2011. Prinsip dasar ilmu gizi. Jakarta : Gramedia pustaka Utama

Arikunto, S. 2012. Prosedur Penelitian Suatu Pendekatan Praktek, Jakarta. Rineka Cipta.

Arisman, Dr MB. 2014. Gizi dalam daur kehidupan: buku ajar ilmu gizi. Jakarta : EGC

Ari Yuniastuti. 2010. Gizi dan Kesehatan. Graha Ilmu. Yogyakarta.

Atikah Proverawati, Siti Asfuah. 2010. Buku Ajar Gizi untuk Kebidanan. Nuha Medika. Yogyakarta

Azwar Azrul. 2009. Metodologi Penelitian Kedokteran dan Kesehatan Masyarakat. Binarupa Aksara. Jakarta 
Devi, Nirmala. 2012. Gizi Anak Sekolah. Grafika Mardi Yuana: Bogor

Hariweni, Trie. 2013. Pengetahuan, Sikap dan Perilaku Ibu Bekerja dan Tidak Bekerja Tentang Stimulasi Pada Pengasuhan Anak Balita, Tesis Bagian Ilmu Kesehatan Anak Fakultas Kedokteran Universitas Sumatera Utara Medan

Hasyim A dan Yusuf M. 2010. Diversifikasi produk ubi jalar sebagai bahan pangan subsitusi beras. www.sinartani.com [10 Januari 2017].

Hidayat, AA. 2010. Metode Penelitian Kebidanan dan Teknik Analisa Data, Edisi I. Salemba Medika. Jakarta

Kartasapoetra, G; Marstyo. 2009. Ilmu Gizi : Korelasi Gizi, Kesehatan dan Produktivitas Kerja. Rineka Cipta. Jakarta Kasjono, dkk. 2009. Tekhnik sampling untuk penelitian kesehatan. Yogyakarta : Graha ilmu

Mikarsa, Hera Lestari, Agus Taufik, dan Puji Lestari Prianto. 2007. Pendidikan Anak di SD. Jakarta: Universitas Terbuka

Mitayani,. 2010. Buku Saku Ilmu Gizi. Jakarta.Tim

Narbuko, Cholid. 2009. Metodologi Penelitian : Memberin bekal teoritis pada mahasiswa tentang metodologi penelitian serta diharapkan dapat melaksanakan penelitian dengan langkah-langkah yang benar. Bumi Aksara. Jakarta

Notoatmodjo, Soekidjo. 2012. Metodologi Penelitian Kesehatan. Jakarta. Rineka Cipta
Notoatmodjo, Soekidjo. 2013. Ilmu Kesehatan Masyarakat Prinsip-Prinsip Dasar. Jakarta. Rineka Cipta

Nursalam. 2009. Pendekatan Praktis Metodologi Riset Keperawatan. Infomedika. Jakarta.

Pariani, siti \& nursalam. 2014. Pendekatan praktis metodologi keperawatan profesional edisi 2. Jakarta : Salemba medika

Proverawati, A. 2010. BBLR (Berat Badan Lahir Rendah). Yogyakarta. Nuha Medika,

Rianto, Theo \& Handoko, Martin, 2014, Pendidikan Anak Usia Dini, Jakarta: Grasindo

Sacharin Rosa M. 2011. Prinsip Keperawatan Pediatrik. Alih bahasa : Maulanny R.F. Jakarta : EGC

Sediaoetama. 2010. Ilmu Gizi. Jakarta: Dian Rakyat

Soetjiningsih. 2013. Perkembangan Anak dan Permasalahannya. In: Narendra MB, Sularyo TS, Soetjiningsih, editors. Tumbuh Kembang Anak dan Remaja. Sagung Seto. Jakarta

Supariasa dkk. 2012. Penilaian Status Gizi. EGC. Jakarta.

Stikes Biges. 2016. Pedoman penyusunan, penulisan, Ujian dan Penilaian karya tulis ilmiah. Polewali : STIkes

Sugiyono. 2010. Metode Penelitian Administrasi. Alfabeta. Bandung

Supariasa, I Dewa nyoman, dkk. 2012. Penilaian status gizi. Jakarta : EGC

Triton, PB. 2010. Mengelola Sumber Daya Manusia. Oryza. Yogyakarta. 
Wahyu, Genis Ginanjar. 2009. Obesitas Pada Anak. Jakarta: Bentang Pustaka

Yupi Supartini. 2014. Buku ajar konsep dasar keperawatan anak. Jakarta. EGC.
Yusuf Syamsu. 2014. Psikologi Perkembangan anak dan Remaja. PT. Remaja Rosdakakarya. Bandung 